\title{
Poética de la Penumbra en la Poesía más Reciente de P. Neruda
}

Hasta Estravagario Neruda se reconoce como el poeta de la claridad, entregado a la "luz de la vida", a las alegrías de todos, a "las luchas de cada día". En el poema que separa, en Tercera residencia, "Las furias y las penas" de España en el corazón, escribe: ". .un salvaje/ cereal ha llegado/ a mi devorada noche/ para que junte mis pasos de lobo/ a los pasos del hombre". 1 . Desde entonces su poesía enredada en "palomas de luto", "otoños negros", "trenes de cieno" y "grandes cenizas" se abre a una claridad que en Odas elementales se define como "mi obligación de luz": "ir y venir por las calles,/ las casas y los hombres/ destruyendo/ la oscuridad. Yo debo/ repartirme/ hasta que todo sea dia,/ hasta que todo sea claridod/ y alegría en la tierra" ( $p$. 968). El lobo cede al hom. bre, la noche, al día, la oscuridad, a la claridad, las furias y las penas, a la alegría. Mucho de la poesía de Neruda posterior a "Las furias y las penas" emerge y se nutre de ese tránsito que en 1951 Amado Alonso describía como "su conversión poética". ${ }^{2}$ En poemas como "Reunión bajo las nuevas banderas", "Explico algunas cosas", "Nuevo canto de amor a Stalingrado", "Alturas de Macchu Picchu", "El poeta", "Carta a Miguel Otero Silva", "A Rafael Alberti" y en general a lo largo de toda su obra, Neruda ha explicado el sentido y alcance de esa conversión. En el último de los poemas mencionados, escribe:

Los pinares del Sur, las razas de la uva dieron a tu diamante cortado sus resinas,

1 Pablo Neruda, Obras completas, Buenos Aires, 1962, pp. 250-251. Los números de página en las citas subsiguientes siguen esta edición. Aqui y más adelante los subrayados son nuestros.

2 Amado Alonso, Estilo y poesia de Pablo Nęrkła, Buenos Aires, 1951. Véase cap. VIII, "la conversión poética de P.N.", 
y al tocar tan hermosa claridad, mucha sombra de la que traje al mundo, se deshizo.

En la sección "Yo soy" de Canto geneval, reitera

La sombra que indagué ya no me pertenece.

Yo tengo la alegría duradera del mástil,

la herencia de los bosques, el viento del camino

y un día decidido bajo la luz terrestre.

(p. 668)

En la ciudad muerta de Macchu Picchu, Neruda encuentra la circuns. tancia apropiada para cantar los abismos de su propia muerte: "... sin lámpara, sin fuego,/ sin pan, sin piedra, sin silencio, solo,/ rodé muriendo de mi propia muerte" (p. 315). Pero Macchu Picchu es también el "alto arrecife de la aurora humana" y desde esa "rosa de piedra" el poeta proclama el nacimiento de un continente y su propio nacimiento:

Sube a nacer conmigo, hermano.

(p. 323)

En la España de la guerra primero, en las ruinas de Macchu Picchu después, -en las minas de Chile más tarde, ${ }^{3}$ Neruda contrae su compromiso con el hombre y sus luchas, con la claridad y la alegría. "El hombre invisible" es tal vez la mejor exégesis de ese compromiso poético. Neruda abre el poema afirmando el valor de toda poesía, aun de aquélla que se regodea $y$ agota cantando "el tiempo y el agua, el cielo y la manzana, el luto y su metal dorado":

yo adoro toda

la poesía escrita,

todo el rocío,

luna, diamante, gota

de plata sumergida,

que fue $\mathrm{mi}$ antiguo hermano,

agregando a la rosa,

(p. 935)

- Véase "Carta a Miguel Otero Silva" en Canto general. 
La última alusión es una referencia a su poesía anterior a la conversión que, a pesar de las supuestas "renegaciones y reprobaciones", Neruda continúa reconociendo como materia de "su rosa", como parte insepara. ble de su mejor poesía. Pero tras esta primera aceptación, la oda toda dibuja un interrogante de reserva hacia "los viejos poetas", hacia "los poetas malditos" que "llevan con gran dificultad la cruz de las tinieblas" y que

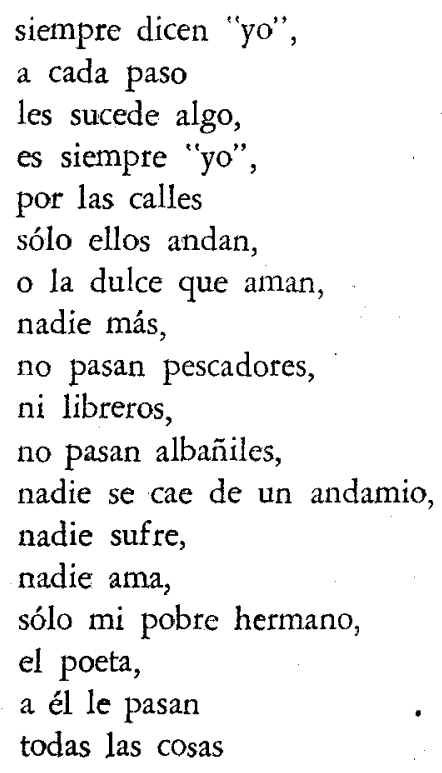

El "viejo poeta" se siente "profundísimo y tenebroso", "se enreda y desenreda", está obligado a las tinieblas e inevitablemente "se hace oscuro". A este poeta que endiosa su yo y cuya sola presencia puebla toda su poesía, Neruda opone el poeta "invisible" que "no tiene tiempo para sus asuntos", cuyo "yo no tiene importancia" y en cuya poesía "todos pasan y todos dicen algo":

cortan maderas, suben hilos eléctricos, amasan hasta tarde en la noche el pan de cada día, 


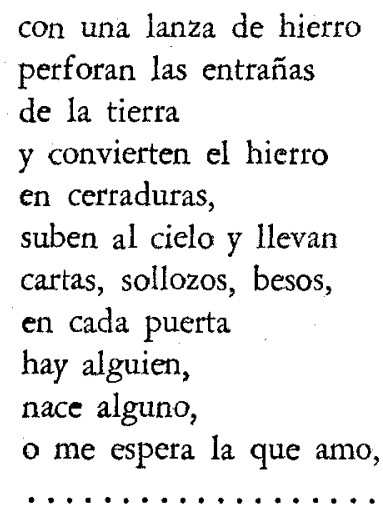

(pp. 937-938)

Al final del poema, Neruda reafirma su compromiso hacia el hom. bre, su fe en la vida, su fidelidad a la alegría, su amistad con la espe. ranza, su condición de cronista de "las luchas de cada dia". No es una casualidad que este poema sea una suerte de pórtico a los cuatro volúmenes de "odas elementales" publicados entre 1954 y 1959: es el resumen más condensado y la mejor definición de su poética de la claridad. Más tarde, en una conferencia de 1964, Neruda describe su empresa como "una larga historia de este tiempo, de las cosas, de los oficios, de las gentes, de las frutas, de las flores, de la vida, de mi visión, de la lucha, en fin, de todo lo que podía englobar de nuevo en un vasto impulso cíclico $\mathrm{mi}$ creación". 4 Desde entonces su poesía ha cumplido esos compromisos con una lealtad comprobable en cualquiera de sus libros posteriores a la conversión. En La barcarola (1967), por ejemplo, se autodefine como "Pablo Neruda, el cronista de todas las cosas" y en Fin de mundo (1969) reitera: "Yo soy el cronista abrumado" 6 y en otro lugar del mismo libro insiste: "Yo soy el cronista irritado/ que no escucha la serenata/ porque tiene que hacer las cuentas/ del siglo verde y su verdura, del siglo nocturno y su sombra,/ del siglo de color de sangre" (pp. 159. 160). En la misma conferencia mencionada, Neruda ha aclarado más aún esta noción del poeta como cronista: "El poeta" - dice- "debe ser, parcialmente, el cronista de su época. La crónica no debe ser quinta. esenciada, ni refinada, ni cultivista. Debe ser pedregosa, polvorienta, lluviosa y cotidiana. Debe tener la huella miserable de los días inútiles

4 En Antología osencial (selección de Hernán Loyola), Buenos Aires, 1971, "Algunas reflexiones improvisadas", p. 327.

5 P. Neruda, La barcarola, Buenos Aires, 1967, p. 127.

- P. Neruda, Fir de mundo, Buenos Aires, 1969, p. 61. 
y las execraciones y lamentaciones del hombre". ${ }^{7}$ Este concepto de poesía como crónica se manifiesta en su obra desde el momento mismo de la conversión: Neruda deja de historiar las búsquedas y agonías de su alma para hacer la crónica poética de su tiempo. El cambio responde, por supuesto, a sus nuevas experiencias vividas, primero, en esa España de la guerra donde Neruda "descubre" el mundo de la historia y lo hace ingresar en su vida. Hasta entonces su poesía había seguido una tradición poética europea cuyo centro es el yo del poeta y cuya materia emerge del extrañamiento de ese yo. A esa tradición alude Neruda en "El hom. bre invisible" cuando habla del "viejo poeta que se declara maldito", y a esa tradición hace referencia en la "Oda a Rimbaud":

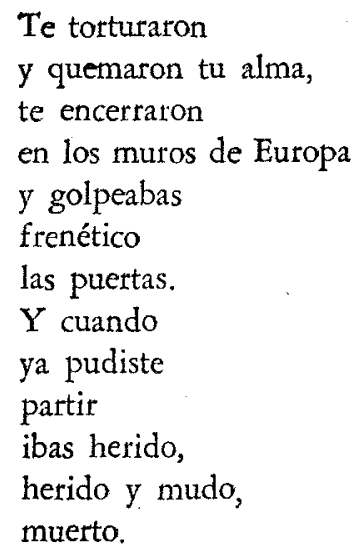

(pp. 1241.1242)

Formado en esa tradición de la poesía europea moderna, Neruda nos presenta un Rimbaud no diferente al Neruda de Residencia, un Rimbaud ahogado en las telarañas y sombras familiares al poeta chileno. Para Ne. ruda esa tradición europea, frecuentemente aludida en su obra como la poesía de "los viejos poetas", representa la oscuridad, un mundo de tinieblas y sombras, de extravíos y angustias, de cuarto cerrado y soledad.

7. Op. cit., p. 326 , En la misma conferencia, Neruda explica las dificultades que el poeta de las Residencias tuvo que enfrentar hasta encontrar ese estilo de crónica: "Mucho me ha sorprendido" - dice- "la no comprensión de estos simples propósitos (el poeta como cronista de su época) que significaron grandes cambios en mi obra, cambios que mucho me costaron. Comprendo que derivé siem. pre hacia la expresión más misteriosa y centrífuga de Residencia en la tierra o de Tentativa, y muy difícil fue para mí llegar al arrastrado prosaismo de ciertos fragmentos del Canto general, que escribi porque sigo pensando que así debieron ser escritos. Porque así escribe el cronista". Antología esencial, p. 326. 
Hasta España en el corazón, su poesía crece estimulada por esa tradición. Un poema como Tentativa del hombre infinito (1925) está construido sobre dos motivos centrales de esa tradición que Baudelaire inaugura y que desemboca en el surrealismo, ${ }^{8}$ y en una carta de 1929 a Héctor Eandi, Neruda escribe: "Residencia en la lierra es un montón de versos de gran monotonía, casi rituales, con misterios y dolores como los hacían los viejos poetas'. En las Residencias Neruda alcanza un modo poético que mejor representa esa tradición, pero vista desde la nueva perspectiva del poeta "convertido" esa poesía reemerge como "un nimbo oscuro": "Los antiguos poetas/ me prestaron anteojos/ y junto a cada cosa/ m nimbo oscuro/ puse,/ sobre la flor una corona negra,/ sobre la boca amada/ un triste beso." ("Oda a la alegtia", p. 946), y a veces como una noche ausente de visiones proféticas y solamente poblada por una oscuridad de muerte:

La noche
me golpeó la nariz
con esa rama
que yo tomé por una
criatura excelente.
La oscuridad es madre
de la muerte
y en ella
el poeta perdido
navegaba
hasta
que una estrella de fósforo
subió o bajó - no supe- .
en las tinieblas.

(p. 1169)

En el mismo poema - "Oda a don Diego de la noche"- menciona dos poetas en cuya obra se sostiene esa tradición poética contra la cual Neruda se vuelve en su nueva poesía: "En el infierno,/ como dos lechuzas,/ Baudelaire y Edgar Poe, / tal vez/ ignorarán mi nombre!" (p. 1169). La poesía de Walt Whitman, en cambio, representa para Neruda esa

8 Esos motivos son "el viaje" y "el infinito" cuyo tratamiento en Tentativa hemos intentado estudiar en "El surrealismo de Tentativa del bombre infinito", Hispanic Review, vol. 40, No. 1, Winter, 1972, pp. 31-39.

- Citado pos Margarita Aguirre, Las vidas de P,N., Santiago 1967, p. 181. 
geografía de la claridad de cuya luz surge el Nuevo Mundo como de un nacimiento:

tú
me enseñaste
a ser americano,
levantaste
mis ojos
a los libros,
hacia
el tesoro
de los cereales:
ancho,
en la claridad
de las llanuras,
me hiciste ver
el alto
monte
tutelar. .
.........

(p. 1276)

Su "Oda a Walt Whitman" no es sino una reafirmación de un reconocimiento ya presente en las páginas de Canto general: "Dame tu voz y el peso de tu pecho enterrado/ Walt Whitman, y las graves/ raíces de tu rostro/ para cantar estas reconstrucciones!" (p. 540). Whitman of rece a Neruda una poética más en armonía con sus nuevos deberes de poeta y su "obligación de luz", una poética que abandona los viejos cantos y las antiguas soledades de la poesía pata enfrentar el destino irrevelado de América. Una paráfrasis más explícita todavía de esa poética aparece en los comentarios hechos por Neruda en Nueva York a propósito de Whitman:

Poetry in South America is a different matter altogether. You see, there are in our countries rivers which have no names, trees which nobody knows, and birds which nobody has described... Our duty, then, as we understand it, is to express what is unheard of. Everything has been painted in Europe, everything has been sung in Europe. But not in America. In that sense, Whitman was a great teacher. Because what is Whitman? He was not only intensely 
conscious, but he was open-eyed! He had tremendous eyes to see everything-he taught us to see things. He was our poet". ${ }^{10}$

Whitman significa para Neruda una ruta ya abierta para llegar a esa América no descubierta y una alternativa a la tradición europea. En la misma entrevista, Neruda reconoce el alto valor de esa tradición y su poesía pero, como en la oda "El hombre invisible", expresa sus reservas:

Mallarmé is a very great French poet. I have sometimes seen photographs of his room-they are full of little beautiful objects... "abanicos"... fans-he used to write beautiful poems on fans. But his rooms were stuffy, all full of curtains, no air. He is a great poet of closed rooms and it seems that many of the new-world poets follow this tradition: they don't open the windows and you not only have to open the windows but come through the windows and live with rivers and animals and beasts. I would say to young poets of my country and of Latin America-perhaps this is our tradition-to discover things, to be in the sea, to be in the mountains, and approach every living thing. ${ }^{11}$

A la oscuridad enrarecida del cuarto cerrado Neruda opone la luminosa claridad de la llanura y la luz reverbetante del océano, a la vieja tradición europea, una nueva poesía de sabor americano que tiene en Whitman su poeta. No se trata de una influencia literaria. Cuando Neruda retoma a Whitman es ya un poeta que ha encontrado su nueva voz. Para Neruda, Whitman representa la realización de una poesía americana que sin prescindir de la tradición europea da expresión a esa realidad auroral del nuevo mundo, de un continente descubierto pero aun innominado.

En "El hombre invisible" escribe Neruda: "Yo quiero/ que todos vivan/ en mi vida/ y canten en mi canto" (p. 938) y esta exhortación a sí mismo ha sido para su poesía algo así como una declaración de principios de su obra posterior a la conversión. Para cumplir tal cometido, la claridad es una condición: "mi obligación es ésa:/ ser transparente", proclama en la "Oda al hombre sencillo" y a lo largo de su poesía posterior a España en el corazón ha formulado una verdadera poética de la claridad. Pero la claridad ha sido siempre la ambición de toda poesía. Cuando la poesía se oscurece es porque, como explica Jean Ro. yère, "siendo como es la historia de un alma busca expresar el misterio

10 "An interview with Pablo Neruda by Robert Bly" en Twenty Poems of Pablo Neruda (tr. by J. Wright and R. Bly), The Sixties Press, 1967, pp. 102-103.

11 Ibid., p. 104. 
de esa alma-pero esta oscuridad es luminosa"12 Es verdad que la nueva índole de la poesía de Neruda ha obligado al poeta a la claridad -an cambio que no ha sido fácil para el autor de Residencia- ${ }^{13}$ pero, al mismo tiempo, es evidente que los nuevos temas de su poesía han facili. tado esa tarea. Condenar la Falange, hacer la crónica de América, celebrar la alcachofa con temas que, sin duda, ponen a prueba hasta a un poeta de la estatura de Neruda, pero esos temas se salvan de la inevitable am. bigüedad que genera toda poesía que intenta comunicar los incomunicables misterios de un alma. ¿Hasta qué punto Neruda ha renunciado a ese segmento de su poesia, hasta qué medida ha puesto una sordina a la intimidad de su propia voz para que en ella se escuchen las voces de todos, hasta dónde ha postergado "sus asuntos" en favor de los asuntos de todos? Son preguntas que Neruda se plantea sin reticencias y a las cuales responde sin ambages en "El hombre invisible". A mitad del poema, sin embargo, chicotea "una ola" que Neruda conoce demasiado bien pero que contiene y sofoca bajo el peso de sus claros deberes de poeta comprometido:

Es verdad que de pronto

me fatigo

y miro las estrellas, me tiendo en el pasto, pasa

un insecto color de violín, pongo el brazo

sobre un pequeño seno

o bajo la cintura

de la dulce que amo,

y miro el terciopelo

duro

de la noche que tiembla

con sus constelaciones congeladas,

entonces

siento subir a mi alma

la ola de los misterios,

(p. 939)

Hasta Estravagario, Neruda levanta un muro de contención que retiene esa "ola de misterios". Para el poeta de las "odas elementales" esos mis-

12 Marcel Raymond, From Baudelaire to Surrealism, New York, 1950, p. 111.

13. Véase nota 7 del presente trabajo. 
terios forman "una noche oscura", un ámbito cerrado cuyo centro es el yo, casi un lujo que se identifica con la oscuridad y, por tanto, prohibido para el poeta de la claridad. En "Oda a la claridad" explica:

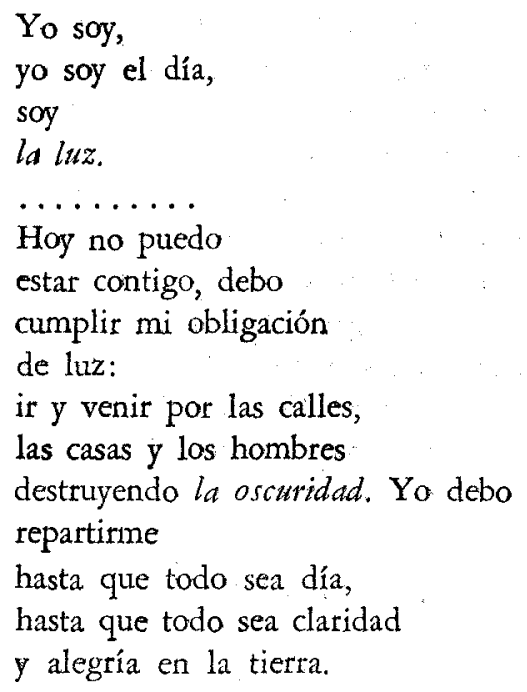

A partir de Estravagario, sin embargo, el poeta realizado en la luz cede a los contornos indefinidos de la sombra. En ese libro, los misterios que han golpeado siempre la frente del poeta encuentran una primera puerta donde se los acoge y escucha. Neruda ha atenuado su atención a esos temas generalmente asociados a la "intratable" oscuridad al otorgar a la poesía de Estravagario un tono sardónico que domina todo el pocmario. Desde el título mismo se advierte un esfuerzo evidente por evitar una ruptura demasiada brusca con su poesía anterior. Como si nos dijera: "el poeta comprometido con la claridad se permite una extravagancia". Medio en broma y medio en serio, Neruda aborda interrogantes y situaciones que ya no pueden plantearse con la prolijidad maniquea del poeta de la claridad. La poesía deja de ser lo que el poeta le pedía que fuera en una de sus odas: "utilitaria y útil,/ como metal o harina,/ dispuesta a ser arado,/ herramienta,/ pan y vino,/ dispuesta, Poesía,/ a luchar cuerpo a cuerpo/ y a caer desangrándote." (p. 1077), para ser simplemente "una alegría sin objeto, / un caballo sólo en el mar, / un telar que tejía viento" (p. 1541). Más significativo aún es que el poeta que decía no tener tiempo para sí mismo en el poema que preludia sus odas elementales, 
nos advierte ahora: "voy a abrirme y voy a encerrarme/ con mi más pér. fido enemigo,/ Pablo Neruda" (p. 1462). Y en efecto en este libro Neruda retorna a episodios y momentos de su vida que pueden no ser "utilitarios y útiles" pero que inevitablemente forman parte de su más intima realidad. En Estravagario se viola ese orden responsable de la causalidad y el compromiso, para alcanzar un orden menos ideal y edifi. cante pero inaplazablemente más humano:

Sin duda todo está muy bien y todo está muy mal, sin duda.

Yo soy profesor de la vida vago estudiante de la muerte y si lo que sé no les sirve no he dicho nada, sino todo.

$$
\text { (p. 1461) }
$$

El poeta que reclamaba de todas las cosas la claridad de la alegría, nos dice ahora: "No hay espacio más ancho que el dolor,/ no hay universo como aquel que sangra" (p. 1461). Los itinerarios de los cuales está hecha la vida no forman una secuencia recta y transparente de lógicas decisiones sino una cadena de inexplicables paradojas: "Para qué me casé en Batavia?", "Qué anduve buscando en Toledo", "Por qué viví en Rangoon de Birmania",

Por qué, por qué tantos caminos, tantas ciudades hostiles?

Qué saqué de tantos mercados?

Cuál es la flor que yo buscaba?

Por qué me moví de mi silla

y me vesti de tempestuoso?

La respuesta de Neruda es apenas una polvorienta imagen en cuya ambigüedad intenta definir lo indefinible:

Nadie lo sabe ni lo ignora:

es lo que pasa a todo el mundo:

se mueve la sombra en la tierra

y el alma del hombre es de sombra por eso se mueve.

(p. 1502) 
"El alma del hombre es de sombra" es una forma de aceptación de esos misterios en cuyas aguas han navegado siempre los poetas pero que Neruda rechazaba como una geografía de la oscuridad, como un mundo de sombras inhabitable para el poeta de la claridad. Pero la oscuridad que se reivindica en Estravagario no es la oscuridad victimaria que devo. raba al poeta de Residencia sino una oscuridad vista desde la claridad, una oscuridad lúcida a la cual Neruda llega después de haber conquistado, como él dice", "la claridad del mundo y la posibilidad de la alegría". De la misma manera acepta ahora la soledad, pero no la soledad primera en la cual se sentía morir el joven poeta de "Sólo la muerte", sino una soledad que es una forma de reencuentro, una soledad que llega al poeta después de haber sentido "la fuerza de todos los que viven". En Estravagario, esos dos rostros de la soledad se enfrentan:

Gracias doy a la tierra

por haberme

esperado

a la hora en que el cielo y el océano

se unen como dos labios,

porque no es poco, no es así? haber vivido

en una soledad y haber llegado a otra,

sentirme multitud y revivitse solo.

$$
\text { (p. 1479) }
$$

En la misma línea de reconocimientos está el rechazo de una identidad exclusiva y excluyente: "Ahora me doy cuenta de que he sido/ no sólo un hombre sino varios" (p. 1454) o, dicho en un tono en el cual se entremezclan humor y sarcasmo:

\footnotetext{
De tantos hombre que soy, que somos, no puedo encontrar a ninguno: se me pierden bajo la ropa, se fueron a otra ciudad. Mientras escribo estoy ausente y cuando vuelvo ya he partido: voy a ver si a las otras gentes les pasa lo que a mí me pasa, si son tantos como soy yo, si se parecen a sí mismos
} 
y cuando lo haya averiguado

voy a aprender $\tan$ bien las cosas

que para explicar mis problemas

les hablaré de geografía.

(pp. 1475-1476)

Finalmente, en la última parte del libro, Neruda aborda el problema de la claridad y la oscuridad en su poesía, y responde por igual a los que antes lo acusaron de oscuro y hoy le echan en cara la sencillez de su poesía. ${ }^{24}$ Pero a diferencia de la actitud adoptada desde la conversión y a lo largo de sus odas elementales, no ataca la oscuridad en nombre de la claridad ni ensalza a ésta a expensas de aquélla. Neruda ha descubierto la validez y necesidad de la una y de la otra. Más aún, plantea la dificultad en deslindar dominios y resuelve el problema con una paradójica respuesta que lo elimina sin resolverlo, tal vez porque lo único falso es el problema mismo:

Dejé mis bienes terrenales

a mi partido y a mi pueblo,

ahora se trata de otras cosas,

cosas tan oscuras y claras

que son sin embargo una sola.

Así sucede con las uvas,

y sus dos poderosos hijos,

el vino blanco, el vino rojo,

toda la vida es roja y blanca,

toda claridad es oscura,

y no todo es tierra $y$ adobe,

hay en mi herencia sombra y sueños.

(p. 1540)

A casi veinticinco años de la segunda Residencia, después de haber librado fogosas batallas por el imperio de la claridad, Neruda retorna en Estravagario a una visión ya intuida en su poema "Apogeo del apio" donde

\footnotetext{
14 En "Contesta a algunos bien intencionados", escribe:

Me preguntaron una vez

por qué escribía tan oscuro, pueden preguntarlo a la noche, al mineral, a las raíces.

Yo no supe qué contestar hasta que luego y después me agredieron dos desalmados acusándome de sencillo. (p. 1540)
} 
intenta comunicar una dialéctica reconciliación de contrarios a través de un oxímoron que reaparecerá en su poesía más tardia: "aquí estoy, en la noche, escuchando secretos,/ desvelos, soledades,/ y entráis, en medio de la niebla hundida,/ hasta crecer en mí, hasta comunicarme/ la luz oscura..." (p. 219). 15 En el mismo "Testamento de otoño", en Estravagatrio, insiste: "los que tienen bosque y agua/ pueden ser sencillos y oscuros" (p. 1542), y en otro lugar: "no le tengo miedo/ a la luz ni a la sombra" (p. 1479). Neruda defiende la oscuridad como un estado de alma que el poeta procura revelar más allá de una equívoca dicotomía que al separar luz y sombra instaura un orden deseable pero ficticio:

No será pues sino que adentro

de mí crecerán cereales,

primero los granos que rompen

la tierra para ver la luz, pero la madre tierra es oscura:

$y$ dentro de mi soy oscuro:

soy como un pozo en cuyas aguas

la noche deja sus estrellas

y sigue sola por el campo.

(p. 1449)

Entre esta oscuridad cuya razón de ser Neruda vindica y la oscuridad que traspasa la poesía abismal de Residencia en la tierra media una diferencia semejante a la que separa las tinieblas antes de $l_{a}$ Creación de la oscuridad de la noche como transitoria ausencia de luz después del día primero. En Residencia, Neruda hace intensa poesía de esos abismos de su ser poblados por una nada de muerte y ciega tiniebla. "Donde puse el pie resbaló mi alma/ hacia las dentaduras del abismo" dirá Neruda más tarde de ese momento de su poesía en Canto general. ${ }^{16}$ La oscuridad que

15 En Memorial de Isla Negra dice "luz sombría" (I, 37), y en Las manos del dia, "luz más oscura" (p. 58), "clara sombra" (p. 97), "transparente tiniebla" (p. 55).

${ }_{16}$ En el mismo poema, "El poeta", explica:

Así nació mi poesía, apenas

rescatada de ortigas, empuñada

sobre la soledad como un castigo,

Aislado así como el agua sombría

que vive en sus profundos corredores,

corrí de mano en mano, al aislamiento

de cada ser, al odio cuotidiano.

La muerte abriendo puertas y caminos.

La muerte deslizándose en los muros. (p. 576) 
revalida Neruda en Estravagario tiene muy poco que ver con esa oscuridad de muerte anterior a España en el corazón y a la cual hace referencia en sus numerosos poemas de autoxégesis. Se trata de una oscuridad de cuya sustancia está hecho el misterio de la vida y que inevitablemente trasciende al lenguaje de la poesía que intenta expresarlo. La oscuridad en el poema deriva de ese esfuerzo del poeta por superar las limitaciones expresivas del lenguaje. En esa operación la claridad discursiva se resiente, como si las intuiciones y entrevisiones del poeta rompieran esos diques de contención conceptual que representa el lenguaje para alcanzar una alquimia de imágenes y símbolos que, como en toda la poesía moderna, más que definir un hallazgo testimonian una búsqueda, más que traducir "poéticamente" una idea o un pensamiento perfectamente definible alu. den a una realidad inédita que se resiste a los agarraderos de la norma. Oscuridad que, en última instancia, busca tocar una claridad negada a la semántica del diccionario y que sólo es tal en relación a esos códigos a los cuales nos ha acostumbrado el llamado lenguaje de la comunica. ción. Cuando ese lenguaje falla, el poeta inventa, con los viejos signos, códigos nuevos, pero sus claves rechazan el dominio del diccionario para instalarse en ese intersticio que forman el texto y el lector.

Después de Estravagario Neruda no abandona sus "deberes" de poeta. Fiel a su compromiso con la luz, consecuente con sus raices americanas, eterno enamorado de la mujer y de si mismo, cronista de todas las cosas, continuará celebrando el amor en libros como Cien sonetos de amor (1959) y La espada encendida (1970), "cantando y contando" las vidas del poeta en su Memorial de Isla Negra (1964), celebrando las piedras y los pájaros en Las piedras de Cbile (1961), Las piedras del cielo (1970) y Arte de pájaros (1966), haciendo la crónica de su tiempo en Fin de mundo (1969), afirmando los poderes del verbo y del poeta en Plenos poderes (1962), pero en libros como La barcarola (1967), Las manos del dia (1968) y Aún (1969) además de continuar remontando esos ríos del canto tan recorridos y tan suyos, además de descubrir nuevos caudales y sorprendernos con inesperados afluentes, Neruda hunde sus manos en esos interrogantes para los cuales el poeta no siempre tiene una respuesta clara y transparente. "A plena luz camino por la sombra" escribe en el último verso de su libro Plenos poderes. El lapidario aserto es una síntesis que conjuga luz y sombra, clatidad y oscuridad. En esa reconciliación se aceptan el día y la noche como condiciones irrevocables del tiempo, "como dos canales, submarinos" - dice Neruda_- "de la vida y el canto". El "poeta vestido de luto" que "con auxilio de la negra noche" indaga lo profético que hay en él, el joven "viejo poeta del mis- 
terio" de Residencia se reconoce en el poeta de la luz y la utilidad, de las cosas elementales y los deberes cotidianos. En el poema que da titulo al libro, "Plenos poderes", dice:

A puro sol escribo, a plena calle, a pleno mar, en donde puedo canto, sólo la noche errante me detiene pero en su interrupción recojo espacio, recojo sombra para mucho tiempo.

El trigo negro de la noche crece mientras mis ojos miden la pradera y así de sol a sol hago las llaves: busco en la oscuridad las cerraduras $y$ voy abriendo al mar las puertas rotas hasta llenar armarios con espuma.

$Y$ no me canso de ir y de volver, no me para la muerte con su piedra, nó me canso de ser y de no ser. ${ }^{1 T}$

En el volumen La luna en el laberinto del Memorial, Neruda reitera esa visión conciliadora de contrarios: ni sólo de luz ni solo de sombra está hecha la vida; como el día que germina de las sombras, también la claridad nace de la oscuridad como creían los viejos poetas:

Tal vez es éste el fin, la verdad misteriosa.

La vida, la continua sucesión de un vacío que de día y de sombra llenaban esta copa $y$ el fulgor fue enterrado como un antiguo príncipe en su propia mortaja de mineral enfermo, hasta que tan tardios ya somos, que no somos: ser $y$ no ser resultan ser la vida. ${ }^{18}$

El poeta de la oscuridad centrado en su yo y el poeta de la claridad que declara no tener tiempo para su yo se reencuentran en esta nueva poética de la reconciliación. Tal reconciliación no ha sida fácil para Neruda que ha debido afrontar la difícil pregunta del escritor que ade.

17 Pablo Neruda, Plenos poderes. Buenos Aires, 1962, pp. 85-86.

18 Pablo Neruda, Memorial de Isla Negra, Buenos Aires, 1964, vol. II, p. 122. 
más del compromiso hacia su arte tiene un compromiso político con su partido: "Debo satisfacer o debo ser?".19 Para un Cortázar el dilema se resuelve sin vacilaciones: el único compromiso del escritor es el compromiso con su arte aunque ese mismo escritor tenga también compromisos hacia su pueblo y su tiempo que debe satisfacer, sin embargo, no a expensas de su arte sino en su capacidad de hombre responsable frente al mundo. Para Neruda, en cambio, la respuesta a tan filosa pregunta es un largo camino de búsquedas, caídas, luchas y hallazgos. Neruda ha respondido siempre con su poesía, pero el poeta que después de la conversión exigía de su poesía "trabajar de lavandera, vender pan en las panaderías, hilar con las sencillas tejedoras, golpear hierros en la metalurgia" (p. 1075), es decir, satisfacer los nuevos deberes sociales que el poeta impone a su poesía, se pregunta ahora perplejo: "Cómo se hipotecó mi poderio/ hasta llegar a no pertenecerme". ${ }^{20}$ Sin renunciar a esos deberes, Neruda retorna, a partir de Estravagario, a la órbita de su ser, a una poesía en que, como decía Amado Alonso, el poeta se plantea "estas preguntas que el hombre se hace a solas consigo mismo".

En Las manos del día Neruda acepta, con un dejo de mea culpa, que sus manos "no han hecho una escoba-Y porque anduve tanto sin quebrar/ los minerales ni cortar madera/ siento que no me pertenece el mundo". ${ }^{21}$ Pero a medida que avanzamos en el poemario ese sentimiento de culpa cede a una voluntad de afirmación, a un anhelo de ser lo que intima y esencialmente somos. Lo que Neruda reconoce en el fondo es que por más "útil y utilitaria" que sea la poesía no puede competir con la utilidad de una escoba o una silla, y que en última instancia los únicos deberes del poeta son los deberes hacia sí mismo y hacia su arte. En el poema "Los soberanos" hay una síntesis apretada de esas culpas y reconocimientos:

Sí, soy culpable

de lo que no hice,

de lo que no sembré, corté, medí,

de no haberme incitado a poblar tierras,

de haberme mantenido en los desiertos

y de mi voz hablando con la arena.

Otros tendrán

más luz en su prontuario,

\footnotetext{
19 Memorial II, p. 116.

20 Loc. cit.

21 Pablo Neruda, Las manos del dia. Buenos Aires, 1968, p. 29. Las citas subsiguientes siguen esta edición.
} 
yo había destinado a tantas cosas crecer en mí, como de la madera se recortan cantando los tablones, que sin hablar de mi alma sino mucho más tarde yo tendré mala nota porque no hice un reloj: no cumplí con $\mathrm{mi}$ deber: se sabe que un reloj es la hermosura.

(p. 46)

Hay aquí una alusión al "hombre invisible", al poeta que posterga su propia voz para que en su canto se oigan las voces de los otros, pero ahora Neruda reconoce los derechos del poeta de hablar de su alma $y$, en la segunda parte del mismo poema, reafirma su fe en la poesía como la creación de ese yo esencial tantas veces acallado, como una construcción que el poeta no decide arbitrariamente ni ejecuta por encargo de nadie sino que lleva en él como los seres más simples de la creación llevan en su ser elemental todas las perfecciones de la hermosura:

La caracola no la puede hacer sino la propia bestia íntima, en su silencio y es propiedad de los escarabajos la errante y enigmática estructura de los siete relámpagos que ostentan.

Pero el hombre que sale con sus manos como con guantes muertos moviendo el aire hasta que se deshacen no me merece la ternura que doy al minuto oceanida o al mínimo coloso coleóptero: ellos sacaron de su propia esencia su construcción y su soberanía.

(p. 46-47)

Aqui reaparece el poeta de Residencia que en las cartas a Héctor Eandi escribía: "Tengo hasta cierto desprecio por la cultura, como interpreta. 
ción de las cosas, me parece mejor un conocimiento sin antecedentes, una absorción física del mundo, a pesar y en contra de nosotros". Y en otra carta: "De mis curiosidades científicas, de mi admiración por los automóviles, de mi atracción por esta naturaleza exótica, bien poco queda, cuando de noche me siento a escribit, solo, frente a un papel. Sólo yo mismo existo entonces, $y$ mis aflicciones, mis felicidades, mis pasiones privadas".22 En Las manos del día Neruda celebra su reencuentro con la noche que no es sino una forma de reencuentro con sus "plenos poderes", con el ser del poeta que pide de su canto: "levanta tu profundidad/ al coro,/ que suban tus raíces/ al coro" (pp. 52.53). Desde esta nueva poesía se tiende un puente donde se reencuentran el poeta nocturno que en uno de sus libros más audaces - Tentativa del bombre infinito- declaraba no saber hacer "el canto de los días": "oh noche huracán muerto resbala tu oscura lava/mis alegrías muerden tus tintas/ mi alegre canto de hombre chupa tus duras mamas" (p. 101), y el poeta de Las manos del día que en "Nacimiento nocturno" reitera: "Amamántame/ noche,/ déjame sacudir,/ vaciar el liquido/ de tus ubres nocturnas, húndeme en tu regazo/ horizontal, entre las poblaciones/ de tu maternidad, por las moradas/ de tus frías antorchas" (p. 55). Pero la noche de este Neruda otonal no es la noche minada de angustias y muerte del poeta de Residencia: es una noche en que luz y oscuridad se reconcilian, una noche a la cual el poeta llega después de un largo viaje, con un traje de sombras pero con los bolsillos llenos de luz:

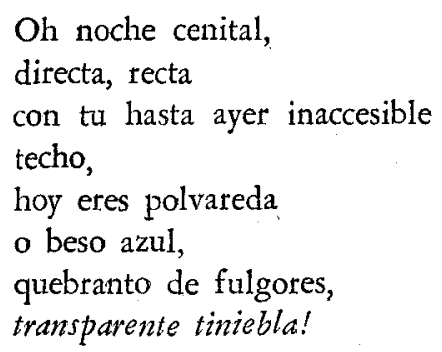

El último verso transporta al nivel de la forma el esfuerzo reconciliatorio presente a lo largo de su poesía más reciente: Neruda ha reencontrado la "luminosa oscuridad" de los "viejos poetas". En este oxímoron, como en otros, ${ }^{23}$ dos nociones aparentemente opuestas - oscuridad y cla-

22 En Las vidas de P. N., op, cit., pp. 181-184.

23 Véase nota 15 de este trabajo. 
ridad - que hasta Estravagario se contradecian y rechazaban, encuentran en su poesía más tardía una síntesis que las integra en una nueva latitud de su viaje poético. Más explícitamente aun escribe en "El viajero" de Las manos del día":

Hombre para penumbra necesito, mujer para penumbra, en esta media tierra estoy vencido:

yo necesito la luz más oscura: sé que otros pueblan

la sombra indeclinable, que la extienden como si fuera alfombra y de otros es la luz, el alfabeto.

Yo no descanso en esta latitud: acabo de llegar:

quiero seguir el viaje.

La palabra "penumbra" define una zona de transición entre la luz y la sombra que no deja percibir dónde empieza la una o acaba la otra. Penumbra describe con precisa ambigüedad la poética de su última poesía: sin desertar la lograda transparencia que remoza la lengua poética de las odas elementales, Neruda dibuja con ese afinado instrumento intuiciones que no son meras transposiciones poéticas de ideas preestablecidas sino intuiciones en el sentido lato de entrevisiones que solamente alcanzan a abrirse en el poema. Es decir, el poema como una revelación, como un misterio que solamente desde y a través de su texto comienza a trans. parentarse. Sin abandonar las superficies de la realidad histórica, sin desertar los volúmenes, colores y demás dimensiones sensoriales en cuyo empleo Neruda es indiscutido maestro, la poesía de Las manos del día cala en esos misterios y reversos que han asediado siempre a los poetas. Sin tendirse al caos de una alquimia verbal que convierte a la palabra en demiúrgica brujería, pero tampoco sin aceptar un orden trazado con regla y escuadra, Neruda retorna a esa "abstracta incertidumbre" donde:

$$
\begin{aligned}
& \text {..........todo } \\
& \text { comienza con palabras, }
\end{aligned}
$$


nuevas palabras que se sientan solas

a la mesa, sin previa invitación, palabras detestables que tragamos y que se meten en nuestros armarios, en nuestras camas, en nuestros amores, hasta que son: hasta que comienza otra vez el comienzo por el verbo.

(pp. 111-112)

La palabra como creación o invención de la realidad, la palabra como signo de una realidad virgen que el poeta busca poseer, la palabra que deja simplemente de significar para ser desde la poesía. Neruda, "el cronista de todas las cosas", cede aquí al poeta inmerso en esos estratos del ser que se resisten a elevaciones y profundidades prolijamente topografiadas. Donde los detectores al uso resultan ineficaces, la poesía instituye medidas y proporciones fuera de escala:

Que la razón no me acompañe más dice mi compañero ( $y$ lo acompaño porque amo, como nadie, el extravío.) Vuelve mi compañero a la razón ( $y$ acompaño otra vez al compañero porque sin la razón no sobrevivo.)

La poesía deja de ser una crónica, crónica que en las "odas" y Canto general restituye a las cosas y a la historia una vitalidad perdida en la costumbre y una fuerza agotada por el tiempo; ahora es un golpe, "un solo golpe" que desata todos los misterios:

Tinta que me entretienes

gota a gota

y vas guardando el rastro

de mi razón y de mi sinrazón

como una larga cicatriz que apenas

se verá, cuando el cuerpo esté dormido

en el discurso de sus destrucciones.

Tal vez mejor hubiera

volcado en una copa

toda su esencia, y haberla arrojado 
en una sola página, manchándola

con una sola estrella verde

y que sólo esa mancha

hubiera sido todo

lo que escribí a lo largo de mi vida,

sin alfabeto ni interpretaciones:

un solo golpe oscuro

sin palabras.

(p. 81)

En este poema, titulado "El golpe", asoma el escritor que desespera del lenguaje. "El golpe" es la versión de Neruda de esa escéptica reflexión -words, words, words - que por un momento enajena al poeta de su instrumento o de ese ideal mallarmeano que concebía al poeta como "músico del silencio"; como si de pronto su fe en el poderío de las palabras se desvaneciera y buscara trascenderlas en un silencio que las neutraliza a todas o en un golpe que las contiene a todas. Pero "el poeta no tiene más remedio que servirse de las palabras y con ellas crear un nuevo lenguaje". ${ }^{24}$ La consecuencia más visible de este alto en la obra de Neruda es una poesía más esencial, una poesía no ya líricamente descriptiva sino meditativamente reflexiva. Deliberadamente Neruda deja de ser el cronista para retornar al concepto más convencional de poeta como indagador de misterios y revelador de esencias. En Las manos del dia penetra más allá de los fenómenos, más allá de esa corteza de concreta realidad cuya belleza llena gran parte de su poesía, para tocar esa zona que nos sacude en nuestras raíces y si nos aleja momentáneamente de la historia es para acercarnos al centro de un ser que busca definirse en términos más absolutos. En Canto genendl, por ejemplo, y a lo largo de las "odas elementales" y el Memorial, Neruda ha hecho la crónica de su vida $y$, en particular, de sus primeros años en el Sur de Chile. El primer volumen del Memorial está dedicado ese periodo y se titula, significa. tivamente, Donde nace la lluvia. Ese pasado del cual nacen largos rios de canto se condensa en Las manos diel dia en ocho versos esenciales:

No volverán aquellos anchos días que sostuvieron, al pasar, la dicha. Un rumor de fermentos como sombrío vino en las bodegas fue nuestra edad. Adiós, 
adiós, resbalan

tantos adioses como las palomas

por el cielo, hacia el Sur, hacia el silencio.

(p. 100)

Neruda no describe la frontera, o los bosques, o su infancia: todo ese pasado ya espléndidamente cantado se resuelve ahora en una despedida, en una nostalgia contenida, en un retorno a ese silencio de los orígenes en cuya "luz sombría" - dice en el Memorial_- "se decidió mi pacto/ con la tierra". Hasta un poema dedicado a Viet Nam participa de esa misma contención. Si se compara este poema, "En Viet Nam", y el titulado "Viet Nam" de Fin de mundo las diferencias se perfilan de inmediato. En Fin de mundo Neruda execra, impreca, plantea la guerra en su inmediatez política, acusa a generales y condena a los "colonialistas": un poema hecho con epítetos, enjuiciamientos y fallos. En Las manos del día, en cambio, la guerra de Viet Nam es presentada en todo su horror humano y en toda su absurda tragedia. En lugar de "estrangulantes" generales y "malvados" gobiernos, Neruda nos habla de una madre muerta, de un hijo muerto, de un padre muerto, de un dolor profundamente humano que nos conmueve más íntima y poderosamente que sus maldiciones o ditirambos.

La poesía de Las manos del día rezuma una serenidad generada por esa fusión reconciliatoria de luces y sombras. Es una penumbra desde la cural las cosas se desdibujan en sus contornos para mejor definirse en profundidad y bajo la cual los detalles importan menos que esa dimensión esencial que mide a las cosas desde dentro. La vida deja de ser una suma de arbitrarias contingencias para recobrar una totalidad cuya forma el poeta nos descubre desde su otoño realizado:

Los días no se descartan ni se suman, son abejas que ardieron de dulzura o enfurecieron el aguijón: el certamen continúa, van y vienen los viajes desde la miel al dolor. No, no se deshila la red de los años: no hay red. no caen gota a gota desde un río: no hay tío. El sueño no divide la vida en dos mitades, ni la acción, ni el silencio, ni la virtud:

fue como una piedra la vida, un solo movimiento, una sola fogata que reverberó en el follaje, 
una flecha, una sola, lenta o activa, un metal

que ascendió y descendió quemándose en tus huesos. ${ }^{25}$

El poema procede de Aum, libro publicado en 1969 y que bien podría definirse como la puesta en práctica de esa poética de la penumbra esbozada a lo largo de Las manos del día. En este libro Neruda pedia de la poesía ser "un solo golpe", "toda la esencia arrojada en una sola página"; ahora nos dice de la vida: "un solo movimiento, una sola fogata, una flecha, una piedra". Lo común en los dos poemas es la visión de vida y poesía no como un conglomerado sino como un todo, no como una suma sino como una indivisa totalidad. Al esencializarse, la poesía de Neruda se concentra y abrevia. Como toda poesia, emerge de esas circunstancias de las cuales Neruda ha ido hilando la crónica de su vida, pero ahora pres. cinde de lo accidental y fragmentario para alcanzar un orden secreto que el poeta percibe a través de condensadas imágenes y crípticos símbolos. Es en esta poesía donde se produce la reconciliación buscada de Estravagario en adelante, reconciliación que no es sino una forma de acep. tación del destino de la poesía como un signo con el cual el poeta se propone releer el mundo y cuyas referenciales no son el acaecer histórico sino sus propias intuiciones. En $A \dot{u} n$ Neruda nos ofrece pequeños com. pendios de sus largos "memoriales", cifras de largas historias, abstractos resúmenes de extensas "navegaciones y regresos" y en algún caso proféticas iluminaciones:
Alguna vez, cerca de Antofagasta, entre las malgastadas vidas del hambre y el círculo arenoso de la pampa, sin ver ni oír me detuve en la nada: el aire es vertical en el desierto: no hay animales (ni siquiera moscas) sólo la tierra, como la luna, sin caminos, sólo la plenitud inferior del planeta, los kilómetros densos de noche y material. Yo allí solo, buscando la razón de la tierra sin hombres y sin alas, poderosa, sola en su magnitud, como si hubiera destruido una por una las vidas para restablecer su silencio.

${ }^{25}$ Pablo Neruda, Aín. Santiago, 1969, p. 48. 
Este poema, como el anterior, como "El pasado", "El golpe", "Moralidades", "Yo no sé nada" y algún otro de Las manos del día, nos pone frente a un Neruda que encuentra un albergue en la soledad. Pero no es la extraviada soledad del poeta de las Residencias; es una soledad rica. mente habitada por las vidas del poeta y otros hombres, es una soledad conquistada desde la cual la vida abandona periferias para alcanzar su centro, hace un alto en sus itinerarios, se aleja del traqueteo de la historia, y en el silencio reencuentra esa forma y núcleo primero que la sostienen.

En la penumbra, seres y cosas comparten un espacio-medio que los osmotiza hasta aunarlos, seres y cosas salen de su aislamiento a que nues. tra razón razonante los ha obligado y se encuentran en "un solo movimiento", en esa flecha disparada que para Neruda es la vida y que en Mundaka Upanishad es un símbolo atmánico más del ser que al tocar el centro del blanco (Braham) se confunde con él y deviene un todo-uno. ${ }^{26}$ Este todo-uno ha sido para los místicos de todas las religiones el espacio infinito que la presencia divina ocupa como su morada, y para los poetas de todos los tiempos el Ser universal que nos contiene a todos y en el cual nos reconocemos. En el poema XVIII de Azin, Neruda se aproxima a la visión del Vedanta que concibe el universo no como un agregado que nuestra lógica de la causalidad ha clasificado y fragmentado en miriadas de fenómenos y sistemas, sino como una totalidad donde hasta la más insignificante de las criaturas participa de esa unidad universal que nos articula y absorbe a todos. El tiempo es una red, dice Neruda, pero agrega: "no hay red"; es un río, dice, y corrige: "pero no hay río". No se trata solamente de distinguir el valor de esas imágenes — red, río como símbolos diferentes de las realidades nominales de las cuales pro. ceden, como podría pensarse después de una primera lectura. Las imágenes de la piedra, el fuego y la flecha que vienen a continuación con. firman el sentido unificador que Neruda les atribuye: son vehículos de esa misteriosa fuerza que otorga a la vida una coherencia universal y que trasciende esos mismos vehículos que la expresan. Dentro de esa Unidad, el tiempo de los días "que se descartan y se suman" cede a un tiempo mágico-religioso, ${ }^{27}$ a un tiempo que descree de la sucesión para instaurar

26 El texto de Mundaka, en su versión inglesa, reza: "Take the great bow of the Upanishads and place in it an arrow sharp with devotion. Draw the bow with concentration on him and hit the centre of the mark, the same everlasting Spirit. The bow is the sacred OM, and the arrow is our own soul. Brahamn is the mark of the arrow, the aim of the soul. Even as an arrow becomes one with its mark, let the watchful soul be one in him". (II, 3-4).

${ }^{27}$ Mircea Eliade llama a este tiempo "Gran Tiempo" o tiempo mítico porque, explica, "myth makes man once more exist in a timeless period, which is in 
un "eterno ahora": esa flecha que se resuelve en "un solo movimien. to" en el poema. Neruda, el poeta de la historia, alcanza aquí el reverso de la historia o su eje o su abstracta materia: esa realidad que se resiste a nuestras categorías lógicas para ser percibida en imágenes sin referentes racionales, en imágenes prelógicas que le restituyen su indescifrable mis. terio y su perdida unidad. El mundo que emerge de ese tiempo total viola nuestras bien delineadas identidades, rompe ese orden de la causalidad en cuyas coordenadas está fijada nuestra realidad, para establecer una identidad cósmica en la cual se reencuentran el niño, la manzana y el anciano. En el poema XXVI de Aún, Neruda escribe:

Si hay una piedra devorada

en ella tengo parte:

estuve yo en la ráfaga,

en la ola,

en el incendio terrestre.

Respeta esa piedra perdida

Si hallas en un camino

$a$ un niño

robando manzanas

$y$ a un viejo sordo

con un acordeón,

recuetda que soy yo

el niño, las manzanas y el anciano.

No me hagas daño persiguiendo al niño, no le pegues al viejo vagabundo, no eches al río las manzanas.

(pp. 63-64)

Si la penumbra es una forma de reconciliación entre la luz y la sombra, entre claridad y oscuridad, ningún poema como éste logra expresar esa reconciliación de manera más definitiva. Hay aquí algo más que una exhortación del tipo que encontramos en los versos finales de "Alturas de Macchu Picchu" donde Neruda declaraba: "Yo vengo a hablar por vuestra boca muerta". En el poema de Aün no se levantan ideales épicos o sociales, no se libra la batalla de la historia, el poeta se deja ser hasta

effect an illud tempus, a time of dawn and of 'paradaise', outside history", Patterns in Comparative Religion, London, 1958, p. 430. 
sentirse y trascender en todas las cosas. En La vuelta al dia en ochenta mundos, escribe Cortázar a propósito de Novalis: "Como los eléatas, como San Agustin, Novalis presintió que el mundo de adentro es la ruta inevitable para llegar de verdad al mundo exterior y descubrit que los dos serán uno solo cuando la alquimia de ese viaje dé un hombre nuevo, el gran reconciliado". Y más adelante explica: "Esa reconciliación con un mundo del que nos ha separado y nos separa un aberrante dua. lismo de raíz occidental, y que el Oriente anula en sistemas y expresiones que sólo de lejos y deformadamente nos alcanzan, puede apenas sospecharse a través de vagas obras". ${ }^{28}$ Entre los ejemplos que cita Cortázar figuran estos versos de Attar:

Tras de beber los mares nos asombra que nuestros labios sigan tan secos como las playas, y buscamos una vez más el mar para mojarnos en él, sin ver que nuestros labios son las playas y no. /sotros el mar

Hay en el poema de Attar una transubstanciación cósmica que es el fundamento del sufismo profesado por Attar y cuyo antecedente es la noción de integración del ser que el Gitc define como una unión a través de la cual el hombre integrado (reconciliado) ve su propio ser' en todas las criaturas y el de todas las criaturas en sí mismo. Neruda puede estar muy lejos, y en verdad lo está, de tales especulaciones místicas, pero la integración y reconciliación que propone su poesía más reciente apuntan a ese mismo esfuerzo de transubstanciación cósmica que trasudan los versos de Attar, a la misma unión universal postulada por los textos vedantas.

Neruda retorna de largos viajes y extensos itinerarios (ninguna geo. grafía le es extraña, ninguna novela es más novelesca que su propia vida) para embarcarse en su última poesía en una travesía hacia adentro que él mismo conoce demasiado bien, pero que ahora nos es un "túnel de ruinas y destrucciones" sino una reconciliación: los hombres y las cosas se reconocen en una misma dimensión, en una sola substancia, en una unidad cósmica donde la vida y la muerte se confunden como la luz y la sombra se confunden en la penumbra. En el último verso de "Es así el destino" de Las manos del dia, escribe: "la vida, es decir la muerte: es decir, la vida". Porque es así, porque la muerte es la realización total de la vida tanto como ésta es el triunfo sobre aquélla, Neruda se asoma a la muerte con la misma serena aceptación que rezuma su última poesía:

28 Julio Cortázar, La vuelta al día en ochenta mundos. México, 1967, p. 207. 
"El enfermo toma el sol" de Las manos del dia cierra con estos endecasílabos:

$Y$ hoy que desamarrado de la cama

ves tanta luz que no cabe en el aire

piensas que si, que si te hubieras muerto

no sólo no hubiera pasado nada

sino que nunca cupo tanta fiesta.

como el bello dia de tu entierro.

(pp. 109-110)

Esta poesía marca el reencuentro con Quevedo, pero no con el Quevedo de "vivimos muriendo para acabar de morir" sino con el poeta del soneto "Cerrar podrá mis ojos la postrera" sobre el cual Neruda había escrito: "Polvo serán, más polvo enamorado". Jamás el grito del hombre alcanzó más altanera resurrección: nunca en nuestro idioma alcanzó la palabra a acumular pólvora tan desbordante. Polvo serán, mas polvo enamorado... Está en este verso el eterno retorno, la perpetua resurrec. ción del amor. Polvo seré, más polvo enamorado... No son Luzbel ni Prometeo, ni los arcángeles de alas exterminadoras. Es la materia humana que, basándose en su propia composición mortal, se sobrepone por primera vez a la destrucción final del ser y las cosas" ${ }^{29}$. En los últimos versos que epilogan Aún Neruda celebra esa resurrección quevediana. Su reconciliación con la muerte es una forma de reconciliación con el mundo y con la vida en su vastedad y diversidad cósmicas. Desde esa totalidad, desde ese movimiento único $e$ imperecedero, las defunciones diarias, nuestra propia muerte es apenas una ola más que la arena absorbe para que nazca otra en ese eterno flujo y reflujo universal donde lo accidental perece para que lo absoluto perdure:

Me muero con cada ola cada día.

Me muero con cada día en cada ola.

Pero el día no muere

nunca.

No muere

Y la ola?

No muere. (p. 68)

Una acotación final. Seria equivocado concluir que esta poética de la penumbra que hemos intentado definir como rasgo distintivo de la

29 Pablo Neruda, Vidjes. Santiago, 1955, p. 34. 
poesía más reciente de Neruda es una orientación exclusiva. No. Después de Las manos del día y Aún, Neruda retorna en libros como Fin del mundo, La espada encendida, Las piedras del cielo, a sus temas de siempre aunque creando formas nuevas, encontrando siempre nuevos rostros $\mathrm{y}$ nuevas voces a sus viejos y siempre nuevos temas. Neruda no es poeta de una sola poética. Su fecundidad es sólo comparable a su extraordinaria capacidad de renovación y cambio. Cada libro suyo es una sorpresa que desafía conjeturas. En su diversidad y riqueza de formas su poesía trasunta de alguna manera la exuberancia del continente que Neruda busca nombrar. Trazar una isobara única que recorra y defina toda su poesía es tan descabellado como intentar representar en un sólo mapa la geografía de un continente. Neruda lo sabe y se burla de los críticos y de sus alfilerazos impacientes aunque bien intencionados: "Yo cambié tantas veces de sol y de arte poética/ que aun estaba sirviendo de ejemplo en cuadernos de melancolia/ cuando ya me inscribieron en los nuevos catálogos de los optimistas, / y apenas me había declarado oscuro como boca de lobo o de perro/ denunciaron a la policía la simplicidad de mi canto. ..", ${ }^{30}$ escribe en La barcarola. La única fidelidad que importa, parece decirnos Neruda, la única lealtad que cuenta es aquélla del poeta hacia su poesía. El último verso del mismo poema reitera, como para que no quede duda, esa fe invencible en el canto:

Yo canto. Yo canto. Yo canto. Yo canto. ${ }^{31}$

JAIme AlazRaki

University of Californid, S. D.

30 Pablo Neruda, La barcarola. Buenos Aires, 1967, p. 39.

31 La barcarola, p. 40. 
